\title{
PEMBUATAN HANDFREE SANITIZER DISPENSER UNTUK WARGA PERUMAHAN PARANGTRITIS VILLA DAGO PAMULANG TANGERANG SELATAN
}

\author{
Ratih Andalusi, Nurul Ashri, A M Irfan \\ Universitas Pamulang \\ Email: dosen01854@unpam.ac.id
}

\begin{abstract}
The purpose of this Community Service is to fulfill one of the Tri Dharma of Higher Education as a form of innovation to society and to contribute to the development and application of science in society. The activity was carried out by researching the community's need for cleanliness, especially during the SARS-CoV-2 pandemic in the residential area of Vila Dago, Parangtritis Cluster, Pamulang, South Tangerang. Socialization of the protocol for healthy and clean living by washing hands and keeping a distance is one way to avoid the SARS-CoV-2 virus. This activity is still being pursued so that people understand how important it is to maintain health. Apart from washing hands, the use of hand sanitizers as an alternative to cleaning hands is also common. Generally, the Handsanitizer used is a gel or liquid in a $250 \mathrm{ml}$ or $500 \mathrm{ml}$ bottle that can be pumped by hand. The use of the hand pump has become a problem. Because of fear of transferring viruses or bacteria, innovation has been made to use the dispenser as a tool that is guaranteed hygienic. The result of community service activities obtained is an instrument or tool in the form of a Hand Sanitizer Dispenser (HSD) which is widely applied in every strategic location in the Vila Dago complex area, Parangtritis Cluster, Pamulang, South Tangerang. A dispenser is made to dispense hand sanitizer without using hands and simply pressing with the feet, to make users feel safer from the spread of the SARS-CoV-2 virus. The target of giving this Handfree Sanitizer Dispenser will be given to residential residents with fairly high mobility of residents at Villa Dago Housing, Parangtritis, Pamulang, South Tangerang. The knowledge obtained at this Community Service is expected to be able to provide enthusiasm, especially for lecturers and other Pamulang University academics in providing material and practice education that has economic value and strategic benefits, as well as motivation and contributing to the public both inside and outside the campus.
\end{abstract}

Keywords: Hand Sanitizer, Dispenser, SARS-CoV-2

\begin{abstract}
ABSTRAK
Tujuan Pengabdian Masyarakat ini adalah untuk memenuhi salah satu Tri Dharma Perguruan Tinggi sebagai bentuk inovasi kepada masyarakat serta menyumbang kontribusi kepada pengembangan serta penerapan keilmuan di tengah masyarakat. Kegiatan dilakukan dengan meriset kebutuhan masyarakat akan kebersihan khususnya di masa pandemi SARS-CoV-2 di
\end{abstract}


Wilayah lingkungan kompleks Vila Dago, Cluster Parangtritis, Pamulang, Tangerang Selatan. Sosialisasi protokol hidup sehat dan bersih dengan mencuci tangan dan menjaga jarak adalah salah satu cara untuk menghindari virus SARS-CoV-2. Kegiatan ini masih terus diupayakan agar masyarakat paham betapa pentingnya menjaga kesehatan. Selain mencuci tangan, penggunaan Hand-sanitizer sebagai alternatif membersihkan tangan juga marak dilakukan. Umumnya, Handsanitizer yang digunakan adalah gel atau cair dalam botol $250 \mathrm{ml}$ atau $500 \mathrm{ml}$ yang dapat di pompa dengan menggunakan tangan. Penggunaan pompa tangan tersebut yang menjadi masalah, Karena khawatir dapat memindahkan virus atau bakteri, untuk itu dilakukan suatu inovasi baru pemanfaatan dispenser sebagai media yang terjamin higienisnya. Hasil kegiatan pengabdian masyarakat yang diperoleh adalah instrument atau alat berupa Hand Sanitizer Dispenser (HSD) yang diaplikasikan secara menyebar disetiap tempat strategis di wilayah kompleks Vila Dago, Cluster Paragntritis, Pamulang, Tangerang Selatan. Dibuatkan dispenser untuk mengeluarkan cairan hand sanitizer tanpa menggunakan tangan dan cukup menekan dengan kaki, dengan tujuan agar pengguna lebih merasa aman dari penyebaran virus SARS-CoV-2. Sasaran pemberian Handfree Sanitizer Dispenser ini akan diberikan kepada warga pemukiman dengan mobilitas warga yang cukup tinggi pada Perumahan Villa Dago, Parangtritis, Pamulang, Tangerang Selatan. Ilmu yang diperoleh pada Pengabdian Masyarakat kali ini diharapkan mampu memberikan semangat khususnya bagi para dosen maupun civitas akademika Universitas Pamulang lainnya dalam memberikan penyuluhan materi serta praktek yang memiliki nilai ekonomis maupun manfaat strategis, serta motivasi serta berkontribusi bagi khalayak masyarakat di dalam maupun luar lingkungan kampus Universitas Pamulang.

Kata Kunci: Hand Sanitizer, Dispenser, SARS-CoV-2

\section{A. PENDAhULUAN}

Infeksi virus Corona disebut COVID-19 (Corona Virus Disease 2019) dan pertama kali ditemukan di kota Wuhan, China pada akhir Desember 2019. Virus ini menular dengan sangat cepat dan telah menyebar ke hampir semua negara, termasuk Indonesia, hanya dalam waktu beberapa bulan. Hal tersebut membuat beberapa negara menerapkan kebijakan untuk memberlakukan lockdown dalam rangka mencegah penyebaran virus Corona. Di Indonesia sendiri, diberlakukan kebijakan Pembatasan Sosial Berskala Besar (PSBB) untuk menekan penyebaran virus ini. Corona virus adalah kumpulan virus yang bisa menginfeksi sistem pernapasan. Pada banyak kasus, virus ini hanya menyebabkan infeksi pernapasan ringan, seperti flu. Namun, virus ini juga bisa menyebabkan infeksi pernapasan berat, seperti infeksi paru-paru (pneumonia).

Virus ini menular melalui percikan dahak (droplet) dari saluran pernapasan, misalnya ketika berada di ruang tertutup yang ramai dengan sirkulasi udara yang kurang baik atau kontak langsung dengan droplet. Selain virus SARS-CoV-2 atau virus Corona, virus yang juga termasuk dalam kelompok ini adalah virus penyebab Severe Acute Respiratory Syndrome (SARS) dan virus penyebab Middle-East Respiratory Syndrome (MERS). Meski disebabkan oleh virus dari kelompok yang sama, yaitu corona virus, COVID-19 memiliki 
beberapa perbedaan dengan SARS dan MERS, antara lain dalam hal kecepatan penyebaran dan keparahan gejala.

Salah satu cara pencegahan yang efektif untuk menangkal virus, bakteri dan microorganism yang dapat menggaggu imunitas tubuh kita adalah dengan menerapkan hidup bersih dan sehat. AlGhamdi et al. (2013) menyatakan bahwa kebersihan kulit terutama tangan merupakan salah satu langkah penting dalam dalam upaya mengurangi transmisi agen infeksi dan mencegah penyebaran penyakit yang disebabkan oleh infeksi. Pencucian tangan merupakan salah satu cara yang sering dilakukan dan dapat mereduksi jumlah bakteri Escherichia coli, S. marcescens, S. aureus, dan P. aeruginosa (Kampf \& Kramer 2004; Sickhert-Bennet et al. 2005). Seiring dengan kemajuan teknologi, terjadi perubahan pola hidup menjadi lebih praktis. penggunaan Hand sanitizer sebagai alternatif membersihkan tangan juga marak dilakukan. Saat ini Hand sanitizer menjadi barang utama yang harus dibawa ketika bepergian. Hand sanitizer merupakan cairan pembunuh bakteri dan microorganisme yang terbuat dari campuran bahan alkohol dan air sebagai kandungan utamanya.

Pada tempat tempat umum seperti restoran, toko, supermarket, kampus, perkantoran saat ini wajib menyediakan Hand sanitizer sebagai antisipasi mengurangi penyebaran virus SARSCov-2. Umumnya, Hand sanitizer yang digunakan adalah gel atau cair dalam botol $100 \mathrm{ml}$, $250 \mathrm{ml}$ atau $500 \mathrm{ml}$ yang dapat dipompa dengan menggunakan tangan. Penggunaan pompa tangan tersebut yang menjadi masalah, karena khawatir dapat memindahkan virus atau bakteri dari botol ke tangan. Pada kegiatan pengabdian masyarakat kali ini, kami akan membuat dispenser/pompa untuk mengeluarkan cairan hand sanitizer tanpa menggunakan tangan, tapi dengan kaki, dengan system injak, dengan tujuan agar pengguna lebih merasa aman dari penyebaran virus SARS-CoV-2. Sasaran pemberian "Handfree Sanitizer Dispenser" ini akan kami berikan kepada warga perumahan dengan mobilitas warga yang cukup tinggi pada Perumahan Villa Dago, Parangtritis RW 20 RT03 Pamulang Tangerang Selatan.

\section{B. METODE PELAKSANAAN KEGIATAN}

Jadwal kegiatan dibagi menjadi 4 tahap yaitu : Proses pencarian metode yang sesuai untuk membuat alat HSD "Handsfree Sanitizer Dispenser", lalu proses pembuatan HSD, dilanjutkan dengan proses uji fungsi alat HSD lalu yang terakhir adalah proses serah terima alat HSD kepada ketua RT 02/20 Warga perumahan Villa Dago Clusters Parangtritis Pamulang Tangerang Selatan. Adapun rincian prosesnya sebagai berikut :

\section{Proses pencarian metode pembuatan alat HSD.}

Tim PKM Universitas Pamulang Prodi Manajemen melakukan peninjauan lokasi daerah sasaran yaitu : Warga perumahan Villa Dago Pamulang Tangsel. Lalu mencari sumber literatur dari internet, jurnal dan media untuk membuat alat praktis, ekonomis dan effisien yang dapat membantu mengurangi penyebaran virus COVID 19.

Dengan waktu selama kurang lebih 1 bulan, akhirnya tim PKM Universitas pamulang menemukan cara untuk membuat alat dengan teknologi ramah lingkungan, yaitu dengan menggunakan paraloh bekas pakai yang akan dimodifikasi menjadi sebuah pompa dengan pedal yang dapat membantu mengeluarkan cairan/gel sanitizer. Pompa tersebut "Handsfree" atau tidak menggunakan tangan, sehingga tangan akan bebas dari kontaminasi permukaan tutup botol/pompa hand sanitizer. Cara kerja dari pompa tersebut untuk mengeluarkan 
cairan/gel sanitizer yaitu dengan pedal yang diinjak menggunakan kaki, tanpa baterai dan listrik, cukup dengan tenaga manual dari kaki. Karena tidak menggunakan tangan, alat tersebut dinamakan HSD atau "HANDSFREE SANITIZER DISPENSER"

\section{Proses pembuatan alat HSD}

Proses pembuatan alat HSD cukup sederhana yaitu :

Bahan :

- 1.5 meter paralon bekas

- Lem Paralon

- Car Warna (Hitam/Biru)

- Gergaji

- Gunting

- Tis pengikat

Cara Pembuatan :

- Potong paralon dengan ukuran :

$12 \mathrm{x}$ ukuran $10 \mathrm{~cm}$

$4 \mathrm{x}$ ukuran $30 \mathrm{~cm}$

$8 \mathrm{x}$ umuran $8 \mathrm{~cm}$

- Sambungkan bagian bagian paralon, lalu lem dengan lem paralon.

- Setelah terangkai, cat dengan cat warna (Piloks) lalu siapkan 1 botol Hand sanitizer ukuran 500ml.

- Letakan botol hand sanitizer pada tempat botol, lalu botol diikat dengan plastik tis.

- HSD siap digunakan.

\section{Proses penyerahan kepada warga}

Alat HSD yang sudah dibuat, akan diserahkan langsung kepada warga dengan lokasi penyerahan di titik-titik yang sudah ditentukan. Ada 6 titik yang sudah disepakati yaitu :

- Musholla at Taubah, Villa Dago Parangtritiis

- Balai Warga RT 03/20 Parangtritis

- Pintu Masuk Clusters Parangtritis

- Pintu Keluar Clusters Parangtritis

- Lapangan Olah Raga Parangtritis

- Taman

\section{HASIL DAN PEMBAHASAN}

Pada kegiatan pengabdian masyarakat kali ini dilakukan di perumahan warga villa dago parangtritis, RW 20/03 Pamulang Tangerang selatan, Banten. Berangkat dari permasalahan yang terdapat di lokasi ketika TIM PKM Universitas Pamulang prodi manajemen datang melakukan analisis situasi, dimana sebagian warga dari perumahan villa dago clusters parangtritis, pamulang sudah mulai banyak yang terinfeksi virus SARS-CoV-2.

Data yang kami dapatkan dari ketua RT setempat Bapak Adi Kasno, jumlah waga yang bermukim di RW 20/03 Sekitar 270 orang. Mayoritas memiliki kegiatan diluar rumah atau bekerja aktif ke kantor. Dengan situasi ini, membuat warga resah, karena khawatir, warga 
yang melakukan mobilitas aktif dapat tidak sengaja membawa virus kedalam clusters perumahan, sehingga akan menularkan virus tersebut ke wilayah perumahan.

Solusi untuk permasalahan diatas, adalah mengikuti protokol kesehatan dengan meminimalisir kontak warga, untuk tetap saling menjaga jarak, menggunakan makser dan mencuci tangan dimanapun atau kapanpun berada. Untuk kegiatan mencuci tangan, kami memiliki alternatif lain, karena pada sarana umum disana tidak memadai untuk menyediakan keran cuci tangan, untuk itu TIM PKM Universitas Pamulang akan mencoba membantu untuk warga villa dago.

Kegiatan yang kami lakukan dimulai dari mencari informasi tentang pembuatan alat bantu untuk mengeluarkan hand sanitizer dengan sistim injak atau dengan kaki. Kami mencari beberapa refferensi model yang mudah, murah dan effektif selama 1 bulan dari bulan oktober hingga November 2019. Akhirnya setelah mencoba beberapa metoda dan bahan, pilihan kami membuat hand sanitizer dispenser dengan sistim injak dengan nama HSD "Handsfree Sanitizer Dispenser".

Bahan dan alat yang digunakan cukup sederhana dan mudah di temukan di sekitar lokasi. Kami menggunakan paralon bekas pakai, lem dan cat paralon untuk membuat HSD tersebut. Berikut adalah gambar proses pembuatan alat HSD yang kami kerjakan selama kurang lebih 1 bulan dari bulan November sampai dengan Desember 2020.

Dalam proses pembuatan alat HSD, kami dibantu oleh beberapa mahasiswa dan mahasiswa UNPAM Prodi Manajemen, Kegiatan ini selain menambah wawasan mereka dan ikut membantu menanggulangi penyebaran virus SARS-CoV-2, juga memberikan mereka pembelajaran, gambaran dan ide peluang wirausaha ditengah masa pandemik COVID 19.

Setelah target pembuatan alat HSD ini selesai delama kurang lebih 1 bulan, tim PKM Universitas Pamulang menyerahkan alat tersebut ke perwakilan warga, yaitu RT setempat untuk dapat di gunakan dan bermanfaat bagi warga setempat. Proses serah terima dilakukan pada tanggal 24 Desember 2020, yang dihadiri oleh beberapa perwakilan warga, perwakilan mahasiswa dan Dosen dari Universitas Pamulang Prodi Manajemen

\section{KESIMPULAN DAN SARAN}

\section{Simpulan}

Kesimpulan dari kegiatan Pengabdian Kepada Masyarakat kali ini adalah kegiatan berlangsung sangat baik, lancar dan bermanfaat. Tim Pengabdian Masyarakat Universitas Pamulang memberikan sumbangan berupa alat pompa HSD "Handsfree Sanitizer Dispenser" kepada warga perumahan Villa Dago clusters parangtritus RW 20/03, Pamulang Tangerang Selatan.

Kegiatan ini berupaya untuk meminamlisisir penyebaran virus COVID 19 yang terjadi dilingkungan warga perumahan tersebut, dimana mayoritas warganya mekalu kegiatan diluar rumah dengan menyediakan media alternatif untuk membersihkan tangan selain mencuci tangan dengan sabun.

Akhirnya, kami mengucapkan terima kasih kepada seluruh pihak yang telah mendukung kegiatan yang kami laksanakan dan kami mohon maaf apabila dalam laporan ini banyak ditemukan kekurangan.

\section{Saran}

Kegiatan PKM ini jika ditindak lanjuti lebih luas tentunya akan bermanfaat. Alat tersebut tidak hanya di rasakan manfaatnya oleh Warga setempat, tapi bisa dirasakan juga untuk wagra sekitar, misalnya di Pasar Tradisional atau tempat umum lainnya. 


\section{Ucapan Terima Kasih}

Rasa syukur dan suka cita kamu haturkan kepada segenap pihak yang telah mensukseskan kegiatan PKM dengan judul "PEMBUATAN HANDFREE SANITIZER DISPENSER UNTUK WARGA PERUMAHAN PARANGTRITIS VILLA DAGO PAMULANG TANGERANG SELATAN" kepada:

1. Rektor Dr. H. Dayat Hidayat, M.M, Rektor Universitas Pamulang Tangerang Selatan Banten.

2. Dr. Ali Maddinsyah, S.E., M.M., selaku Ketua LPPM Universitas Pamulang Tangerang Selatan - Banten.

3. Dr. Kasmad, S.E., M.,M., selaku Ketua Program Studi Manajemen Universitas Pamulang Tangerang Selatan - Banten.

4. Dr. Udin Ahidin, S.E., M.M., C.M.A, Selaku Wakil Program Studi Manajemen Universitas Pamulang Tangerang Selatan - Banten.

5. Drs. Waluyo Jati, M.M., Selaku Sekretaris Program Studi Manajemen Universitas Pamulang Tangerang Selatan - Banten.

6. Ketua Rukun Tetangga (RT) 02/20, beserta warga Perumahan Vila Dago Cluster Parangtritis atas kerjasama dan kesempatannya dalam pelaksanaan Pengabdian Masyarakat periode ini.

\section{DOKUMENTASI KEGIATAN}
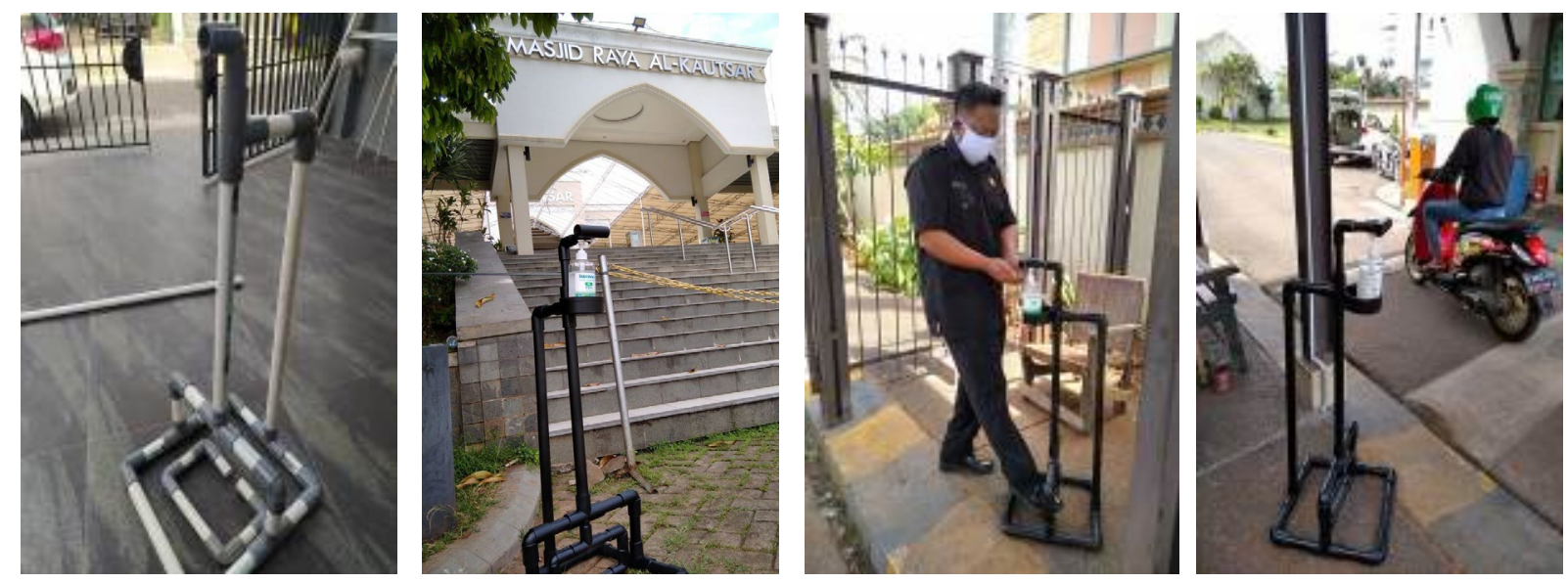

\section{DAFTAR PUSTAKA}

Abdjulu, Ayu Isnawati (2019). Formulasi Dan Uji Stabilitas Sediaan Spray Gel Hand Sanitizer Kombinasi Minyak Atsiri Geranium (Pelargonium Graveolens) Dan Minyak Atsiri Pepermin (Mentha Piperita). Undergraduate (S1) Thesis, University Of Muhammadiyah Malang

Am Irfanudin, E Kurniawati, Jamaluddin, R Andalusi, Noryani. (2020). Strategi Berbisnis Online Ditengah Pandemi Corona Virus Disease 2019 Covid-19. Dedikasi Pkm, Vol.1(2)

Cicaningsih, A., \& Cahyono, T. (2018). Komparasi Efektivitas Hand Sanitizer Alami "Ac" Dan Merk E Terhadap Penurunan Angka Kuman Pada Tangan Pekerja Di Labkesmas Kabupaten Banyumas Tahun 2017. Buletin Keslingmas, 37(3), 364-373. 
Dampuk, B. J. (2018). Uji Aktivitas Antibakteri Kombinasi Ekstrak Etanol Biji Mahoni (Swietenia Mahagoni Jacq.) Dan Daun Sirih (Piper Betle L.) Terhadap Staphylococcus Aureus Dengan Metode Difusi (Doctoral Dissertation, Universitas Setia Budi Surakarta).

Dewi, D. W. (2016). Pemanfaatan Infusa Lidah Buaya (Aloe Vera L) Sebagai Antiseptik Pembersih Tangan Terhadap Jumlah Koloni Kuman (Doctoral Dissertation, Tanjungpura University).

Lestari, P. M., \& Pahriyani, A. (2018). Pelatihan Pembuatan Hand Sanitizer Perasaan Buah Jeruk Nipis Bagi Guru, Siswa Siswi Sma Dan Smk Mutiara 17 Agustus Kelurahan Teluk Pucung Bekasi Utara. Semar. Jurnal Ilmu Pengetahuan, Teknologi, Dan Seni Bagi Masyarakat), 7(1).

Jauhari, J. (2010). Upaya Pengembangan Usaha Kecil Dan Menengah (Ukm) Dengan Memanfaatkan E-Commerce. Jurnal Sistem Informasi (Jsi), Vol. 2., No. 1, 159-168.

Jurnal.Id. (2019, Maret 12). Retrieved From Https://Www.Jurnal.Id: Https://Www.Jurnal.Id/Id/Blog/Strategi-Bisnis-Untuk-Bersaing-Di-Era-Digital/

Kasali, R., \& Dkk. (2010). Modul Kewirausahaan. Jakarta: Hikmah (Pt Mizan Publika).

Keputusan Presiden Republik Indonesianomor 11 Tahun 2020 Tentang Penetapan

Kedaruratan Kesehatan Masyarakat Corona Virus Disease 2019 (Covid- 19);

Peraturan Pemerintah Republik Indonesia Nomor 21 Tahun 2020 Tentang Pembatasan Sosial Berskala Besar Dalam Rangka Percepatan Penanganan Corona Virus Disease 2019 (Covid-19);

Peraturan Menteri Pendidikan Dan Kebudayaan Republik Indonesia Nomor 3 Tahun 2020 Tentang Standar Nasional Pendidikan Tinggi;

Peraturan Menteri Pendidikan Dan Kebudayaan Republik Indonesia Nomor 7 Tahun 2020 Tentang Pendirian, Perubahan, Pembubaran Perguruan Tinggi Negeri, Dan Pendirian, Perubahan, Pencabutan Izin Perguruan Tinggi Swasta;

Surat Keputusan Menteri Kesehatan Nomor Hk.01.07 /Menkes/239/2020, Tentang Penetapanpembatasan Sosial Berskala Besar Di Wilayah Provinsi Dki Jakarta Dalam Rangka Percepatan Penanganan Corona Virus Disease 2019 (Covid 19);

Ward, John, Peppard, Joe. (2002). Strategic Planning For Information System. 3rd Edition. John Willey \& Sons, Buffins Lane, Chichester. 